\title{
PENDIDIKAN KARAKTER MENURUT PERSPEKTIF IMAM IBNU QOYYIM AL JAUZIYAH
}

\section{Pendidikan Karakter}

Pendidikan karakter berasal dari dua kata "pendidikan dan karakter" menurut beberapa ahli, kata pendidikan mempunyai definisi yang berbeda-beda tergantung pada sudut pandang, paradigma, metodologi dan disiplin keilmuan yang digunakan, diantaranya : Menurut D. Rimba, pendidikan adalah "Bimbingan atau pembinaan secara sadar oleh pendidik terhadap perkembangan Jasmani dan Rohani anak didik menuju terbentuknya kepribadian yang utuh. ${ }^{1}$

Menurut Doni Koesoema A. mengartikan pendidikan sebagai proses internalisasi budaya ke dalam diri individu dan masyarakat menjadi beradab. ${ }^{2}$ Ada pula yang mendefinisikan pendidikan sebagai proses dimana sebuah bangsa mempersiapkan generasi mudanya untuk menjalankan kehidupan, dan untuk memenuhi tujuan hidup secara efektif dan efisien.

Menurut Sudirman N. pendidikan adalah usaha yang dijalankan oleh seseorang atau sekelompok orang untuk mempengaruhi seseorang atau sekelompok orang lain agar menjadi dewasa atau mencapai tingkat hidup dan penghidupan yang lebih tinggi dalam arti mantap. ${ }^{3}$ Ki Hadjar Dewantara menyatakan bahwa pendidikan adalah daya upaya untuk memajukan budi pekerti, pikiran, dan jasmani anak agar selaras dengan alam dan masyarakatnya. ${ }^{4}$ Sedangkan secara terminologi, pengertian pendidikan banyak sekali dimunculkan oleh para pemerhati/tokoh pendidikan, di antaranya: Pertama, menurut Marimba pendidikan adalah bimbingan atau pimpinan secara sadar oleh pendidik terhadap perkembangan jasmani dan rohani anak didik menuju terbentuknya kepribadian yang utama. ${ }^{5}$

Dalam Undang-Undang Nomor 20 Tahun 2003 tentang Sistem Pendidikan Nasional dalam Pasal 1 ayat (1) disebutkan bahwa pendidikan adalah usaha sadar dan terencana untuk mewujudkan suasana belajar dan proses pembelajaran agar anak didik secara aktif mengembangkan potensi dirinya untuk memiliki kekuatan spiritual keagamaan, pengendalian diri, kepribadian, kecerdasan, akhlak mulia, serta keterampilan yang diperlukan dirinya, masyarakat, bangsa dan negara. ${ }^{6}$ Intinya pendidikan selain sebagai proses humanisasi, pendidikan juga merupakan usaha untuk membantu manusia mengembangkan seluruh potensi yang dimilikinya (olahrasa, raga dan rasio) untuk mencapai kesuksesan dalam kehidupan dunia dan akhirat.

Setelah kita mengetahui esensi pendidikan secara umum, maka yang perlu diketahui selanjutnya adalah hakikat karakter sehingga bisa ditemukan pengertian pendidikan karakter secara komprehensif.

\footnotetext{
${ }^{1}$ D. Marimba, Pengantar Filsafat Pendidikan Islam, (Bandung: Al-Ma'arif, 1989), h. 19.

2 Doni Koesoema A. Pendidikan Karakter: Strategi Mendidik Anak di Zaman Modern. (Jakarta: Grasindo, 2007), h. 80

${ }^{3}$ Sudirman N, Ilmu Pendidikan, (Bandung: Remaja Rosdakarya, 1987), h.

${ }^{4}$ Ki Hadjar Dewantara. Pendidikan. (Yogyakarta: Majelis Luhur Persatuan Taman Siswa), h. 14.

${ }^{5}$ Ahmad Tafsir, Ilmu Pendidikan dalam Perspektif Islam, (Bandung: PT Remaja Rosdakarya, 2005), h.24.

${ }^{6}$ UU RI Tahun 2005 tentang Guru dan Dosen serta UU RI No. 20 Tahun 2003 tentang Sisdiknas, Ibid. h. 74
} 
Istilah karakter digunakan secara khusus dalam konteks pendidikan baru muncul pada akhir abad 18, terminologi karakter mengacu pada pendekatan idealis spiritualis yang juga yang juga dikenal dengan teori pendidikan normatif, dimana yang menjadi prioritas adalah nilai-nilai transenden yang dipercaya sebagai motivator dan dominisator sejarah baik bagi individu maupun bagi perubahan nasional. Istilah karakter berasal dari bahasa Yunani, charassein, yang berarti to engrave atau mengukir. Membentuk karakter diibaratkan seperti mengukir di atas batu permata atau permukaan besi yang keras. Dari sanalah kemudian berkembang pengertian karakter yang diartikan sebagai tanda khusus atau pola perilaku (an individual's pattern of behavior ... his moral contitution).

Sedangkan Istilah karakter secara harfiah berasal dari bahasa Latin "Charakter", yang antara lain berarti: watak, tabiat, sifat-sifat kejiwaan, budi pekerti, kepribadian atau akhlak. Sedangkan secara istilah, karakter diartikan sebagai sifat manusia pada umumnya dimana manusia mempunyai banyak sifat yang tergantung dari faktor kehidupannya sendiri. Karakter adalah sifat kejiwaan, akhlak atau budi pekerti yang menjadi ciri khas seseorang atau sekelompok orang. ${ }^{7}$ karakter juga bisa diartikan sikap, tabiat, akhlak, kepribadian yang stabil sebagai hasil proses konsolidasi secara progresif dan dinamis. ${ }^{8}$

Sementara dalam Kamus Bahasa Indonesia kata 'karakter' diartikan sebagai tabiat, sifat-sifat kejiwaan, akhlak atau budi pekerti yang membedakan seseorang dangan yang lain, dan watak. Ki Hadjar Dewantara memandang karakter sebagai watak atau budi pekerti. Menurutnya budi pekerti adalah bersatunya antara gerak fikiran, perasaan, dan kehendak atau kemauan yang kemudian menimbulkan tenaga.

Dari beberapa definisi karakter tersebut dapat disimpulkan secara ringkas bahwa karakter adalah sikap, tabiat, akhlak, kepribadian yang stabil sebagai hasil proses konsolidasi secara progresif dan dinamis; sifat alami seseorang dalam merespons siruasi secara bermoral; watak, tabiat, akhlak, atau kepribadian seseorang yang terbentuk dari hasil internalisasi berbgai kebajikan, yang diyakini dan digunakan sebagai landasan untuk cara pandang, berpikir, bersikap dan bertindak; sifatnya jiwa manusia, mulai dari angan-angan sampai menjelma menjadi tenaga.

Dari definisi yang telah disebutkan terdapat perbedaan sudut pandang yang menyebabkan perbedaan pada pendefinisiannya. namun demikian, jika melihat esensi dari definisi-definisi tersebut ada terdapat kesamaan bahwa karakter itu mengenai sesuatu yang ada dalam diri seseorang, yang membuat orang tersebut disifati.

Mengacu pada berbagai pengertian dan definisi tentang pendidikan dan karakter secara sederhana dapat diartikan bahwa pendidikan karakter adalah upaya sadar yang dilakukan seseorang atau sekelompok orang (pendidik) untuk menginternalisasikan nilai-nilai karakter pada seseorang yang lain (peserta didik) sebagai pencerahan agar peserta didik mengetahui, berfikir dan bertindak secara bermoral dalam menghadapi setiap situasi. Banyak para ahli yang mengemukakan pendapatnya tentang pendidikan karakter, diantaranya Lickona yang mendefinisikan pendidikan karakter sebagai upaya yang sungguh-sungguh untuk membantu seseorang memahami, peduli dan bertindak dengan landasan nilai-nilai etis.

\footnotetext{
7 Abdul majid, Dian andayani. Pedidikan karakter dalam perspektif Islam. (Bandung: Insan Cita Utama, 2010), hlm. 11

8 Yahya Khan. Pendidikan Karakter Berbasis Potensi Diri: Mendongkrak Kualitas Pendidikan. (Yogyakarta: Pelangi Publishing, 2010), h. 1.
} 
Pendidikan karakter menerut Lickona mengandung tiga unsure pokok, yaitu mengetahui kebaikan (knowing the good), mencintai kebaikan (desiring the good), dan melakukan kebaikan (doing the good).

Thomas Lickona mendefinisikan orang yang berkarakter sebagai sifat alami seseorang dalam merespons situasi secara bermoral yang dimanifestasikan dalam tindakan nyata melalui tingkah laku yang baik, jujur, bertanggung jawab, menghormati orang lain dan karakter mulia lainnya. Pengertian ini mirip dengan apa yang diungkapkan oleh Aristoteles, bahwa karakter itu erat kaitannya dengan "habit" atau kebiasaan yang terus menerus dilakukan. Lebih jauh, Lickona menekankan tiga hal dalam mendidik karakter. Tiga hal itu dirumuskan dengan indah: knowing, loving, and acting the good. Menurutnya keberhasilan pendidikan karakter dimulai dengan pemahaman karakter yang baik, mencintainya, dan pelaksanaan atau peneladanan atas karakter baik itu. ${ }^{9}$

Pendidikan Karakter menurut Albertus adalah diberikannya tempat bagi kebebasan individu dalam mennghayati nilai-nilai yang dianggap sebagai baik, luhur, dan layak diperjuangkan sebagai pedoman bertingkah laku bagi kehidupan pribadi berhadapan dengan dirinya, sesame dan Tuhan. ${ }^{10}$

Menurut Khan pendidikan karakter adalah proses kegiatan yang dilakukan dengan segala daya dan upaya secara sadar dan terencana untuk mengarahkan anak didik. Pendidikan karakter juga merupakan proses kegiatan yang mengarah pada peningkatan kualitas pendidikan dan pengembangan budi harmoni yang selalu mengajarkan, membimbing, dan membina setiap menusiauntuk memiliki kompetensi intelektual, karakter, dan keterampilan menarik. Nilai-nilai pendidikan karakter yang dapat dihayati dalam penelitian ini adalah religius, nasionalis, cerdas, tanggung jawab, disiplin, mandiri, jujur, dan arif, hormat dan santun, dermawan, suka menolong, gotong-royong, percaya diri, kerja keras, tangguh, kreatif, kepemimpinan, demokratis, rendah hati, toleransi, solidaritas dan peduli.

Ada sembilan pilar karakter yang berasal dari nilai-nilai luhur universal, yaitu :

1. karakter cinta Tuhan dan segenap ciptaan-Nya

2. kemandirian dan tanggung jawab

3. kejujuran/amanah, diplomatis

4. hormat dan santun

5. dermawan, suka tolong menolong dan gotong royong/kerjasama

6. percaya diri dan pekerja keras

7. kepemimpinan dan keadilan

8. baik dan rendah hati

9. karakter toleransi, kedamaian, dan kesatuan. ${ }^{12}$

Kesembilan karakter itu, perlu ditanamkan dalam pendidikan holistik dengan menggunakan metode knowing the good, feeling the good, dan acting the good. Hal tersebut diperlukan agar anak mampu memahami, merasakan/mencintai dan sekaligus melaksanakan nilai-nilai kebajikan. Bisa dimengerti, jika penyebab

\footnotetext{
${ }^{9}$ Thomas Lickona, Educating For Character: How Our School Can Teach Respect and Responsibility, (New York:Bantam Books,1992) , h. 12-22.

${ }^{10}$ Albertus, Doni Koesoema, Pendidikan Karakter Strategi Mendidik Anak di Zaman Global, (Jakarta: PT.Grasindo, 2010), h.5.

${ }^{11}$ Yahya Khan, Pendidikan Karakter Berbasis Potensi Diri, (Yogyakarta : Pelangi Publishing, 2010), h. 34.

12 Thomas Lickona, Educating For Character, Ibid. h. 12-22.
} 
ketidakmampuan seseorang untuk berperilaku baik, walaupun secara kognitif anak mengetahui, karena anak tidak terlatih atau terjadi pembiasaan untuk melakukan kebajikan

Menurut Ramli, pendidikan karakter memiliki esensi dan makna yang sama dengan pendidikan moral dan pendidikan akhlak. Tujuannya adalah membentuk pribadi anak, supaya menjadi manusia yang baik, warga masyarakat yang baik dan warga Negara yang baik. Adapun kriteria manusia yang baik, warga masyarakat yang baik, dan warga Negara yang baik bagi suatu masyarakat atau bangsa, secara umum adalah nilai-nilai sosial tertentuyang banyak dipengaruhi oleh budaya masyarakat dan bangsanya. Oleh karena itu, hakikat pendidikan karakter dalam konteks pendidikan Indonesia adalah pendidikan nilai, yakni pendidikan nilai-nilai luhur yang bersumber dari budaya bangsa Indonesia sendiri, dalam rangka membina kepribadian generasi muda. ${ }^{13}$

Pendidikan karakter juga dapat dimaknai sebagai upaya yang terencana untuk menjadikan peserta didik mengenal, peduli, dan menginternalisasikan nilai-nilai sehingga peserta didik menjadi insan kamil. Pendidikan karakter juga dapat diartikan sebagai suatu system penanaman nilai-nilai karakter kepada warga sekolah yang meliputi komponen pengetahuan, kesadaran atau kemauan dan tindakan untuk melaksanakan nilai-nilai tersebut baik terhadap Tuhan Yang Maha Esa, diri sendiri, sesana, lingkungan maupun kebangsaan sehingga menjadi manusia yang sempurna.

Penanaman nilai pada warga sekolah maknanya bahwa pendidikan karakter baru akan efektif jika tidak hanya siswa, tetapi juga para guru, kepala sekolah dan tenaga non-pendidik disekolah harus terlibat dalam pendidikan karakter.

Pendidikan karakter adalah proses menanamkan karakter tertentu sekaligus memberi benih agar peserta didik mampu menumbuhkan karakter khasnya pada saat menjalankan kehidupan. Dengan kata lain, peserta didik tidak hanya memahami pendidikan sebagai bentuk pengetahuan, namun juga menjadikan sebagai bagian dari hidup dan secara sadar hidup berdasarkan pada nilai tersebut.

\section{Tujuan Pendidikan Karakter}

Pada dasarnya Pendidikan karakter bertujuan untuk meningkatkan mutu penyelenggaraan dan hasil pendidikan yang mengarah pada pencapaian pembentukan karakter atau akhlak mulia peserta didik secara utuh, terpadu, dan seimbang, sesuai standar kompetensi lulusan. Melalui pendidikan karakter diharapkan peserta didik mampu secara mandiri meningkatkan dan menggunakan pengetahuannya, mengkaji dan menginternalisasi serta mempersonalisasi nilai-nilai karakter dan akhlak mulia sehingga terwujud dalam perilaku sehari-hari.

Pendidikan adalah pendidikan budi pekerti plus, yaitu yang melibatkan aspek teori pengetahuan (cognitive), perasaan (feeling), dan tindakan (action). Menurut Thomas Lickona, tanpa ketiga aspek ini, maka pendidikan karakter tidak akan efektif, dan pelaksanaannya pun harus dilakukan secara sistematis dan berkelanjutan.

Melalui pendidikan karakter, seorang anak akan menjadi cerdas, tidak hanya otaknya namun juga cerdas secara emosi. Kecerdasan emosi adalah bekal terpenting dalam mempersiapkan anak menyongsong masa depan. Dengan kecerdasan emosi, seseorang akan dapat berhasil dalam menghadapi segala macam tantangan, termasuk tantangan untuk berhasil secara akademis.

\footnotetext{
${ }^{13}$ Heri Gunawan, Pendidikan Karakter Konsep dan Implementasi, (Bandung:Alfabeta, 2012) , h.23-24.
} 
Hal ini sesuai dengan rumusan tujuan pendidikan nasional yang terdapat pada UUSPN No.20 tahun 2003 Bab 2 pasal 3: Pendidikan Nasional berfungsi mengembangkan kemampuan dan membentuk watak serta peradaban bangsa yang bermartabat dalam rangka mencerdaskan kehidupan bangsa, bertujuan untuk berkembangnya potensi anak didik agar menjadi manusia yang beriman dan bertakwa kepada Tuhan Yang Maha Esa, berakhlak mulia, sehat, berilmu, cakap, kreatif, mandiri, dan menjadi warga negara yang demokratis serta bertanggung jawab. $^{14}$

Sedangkan dari segi pendidikan, pendidikan karakter bertujuan untuk meningkatkan mutu penyelenggaraan dan hasil pendidikan yang mengarah pada pencapaian pembentukan karakter dan akhlak mulia peserta didik secara utuh, terpadu dan seimbang.

Pendidikan karakter pada intinya bertujuan untuk membentuk bangsa yang tangguh, kompetitif, nerakhlak mulai, bermoral, bertoleran, ber gotongroyong, berjiwa patriotik, berkembag dinamis, beroreantasi pada ilmu pengetahuan dan teknologi yang semuanya dijiwai oleh iman dan taqwa kepada Tuhan Yang Maha Esa berdasarkan Pancasila. ${ }^{15}$

\section{Nilai-nilai Dalam Pendidikan Karakter}

Pendidikan karakter berpijak dari karakter dasar manusia, yang bersumber dari nilai moral universal (bersifat absolut) yang bersumber dari agama yang juga disebut sebagai the golden rule. Pendidikan karakter dapat memiliki tujuan yang pasti, apabila berpijak dari nilai-nilai karakter dasar tersebut.

Menurut para ahli psikolog, beberapa nilai karakter dasar tersebut adalah: cinta kepada Allah dan ciptaan-Nya (alam dengan isinya), tanggung jawab, jujur, hormat dan santun, kasih sayang, peduli, dan kerjasama, percaya diri, kreatif, kerja keras, dan pantang menyerah, keadilan dan kepemimpinan; baik dan rendah hati, toleransi, cinta damai, dan cinta persatuan.

Pendidikan karakter dianggap sebagai pendidikan nilai moralitas manusia yang disadari dan dilakukan dalam tindakan nyata. Tampak di sini terdapat unsur pembentukan nilai tersebut dan sikap yang didasari pada pengetahuan untuk melakukannya. Nilai-nilai itu merupakan nilai yang dapat membantu interaksi bersama orang lain secara lebih baik (learning to live together). Nilai tersebut mencakup berbagai bidang kehidupan, seperti hubungan dengan sesama (orang lain, keluarga), diri sendiri (learning to be), hidup bernegara, lingkungan dan Tuhan. ${ }^{16}$ Tentu saja dalam penanaman nilai tersebut membutuhkan tiga aspek, baik kognitif, afektif maupun psikomotorik.

Senada dengan yang diungkapkan oleh Lickona, yang menekankan tiga komponen karakter yang baik, yaitu moral knowing (pengetahuan tentang moral), moral feeling (perasaan tentang moral), dan moral action (perbuatan moral). Sehingga dengan komponen tersebut, seseorang diharapkan mampu memahami, merasakan dan mengerjakan nilai-nilai kebajikan. ${ }^{17}$

\footnotetext{
${ }^{14}$ Dharma Kesuma, et.al, Pendidikan Karakter Kajian Teori dan Praktik di Sekolah (Bandung: Remaja Rosdakarya, 2011), 6.

${ }^{15}$ Heri Gunawan, Pendidikan Karakter Konsep dan Implementasi. (Bandung: Alfabeta, 2012), 30

${ }^{16}$ Masnur Muslih, Pendidikan Karakter Menjawab Tantangan Krisis Multidimensional (Jakarta; Bumi Aksara, 2011), 67.

17 Lickona bernama lengkap Thomas Lickona, merupakan salah satu tokoh pemikir pendidikan karakter kontemporer. Ia memiliki pandangan, bahwa terjadi dikotomi antara pendidikan karakter
} 
Lebih lanjut, Kemendiknas melansir bahwa berdasarkan kajian nilai-nilai agama, norma-norma sosial, peraturan atau hukum, etika akademik, dan prinsipprinsip HAM, telah teridentifikasi 80 butir nilai karakter yang dikelompokkan menjadi lima, yaitu:

1. Nilai-nilai perilaku manusia yang berhubungan dengan Tuhan Yang Maha Esa

2. Nilai-nilai perilaku manusia yang berhubungan dengan diri sendiri

3. Nilai-nilai perilaku manusia yang berhubungan dengan sesama manusia

4. Nilai-nilai perilaku manusia yang berhubungan dengan lingkungan

5. nilai-nilai perilaku manusia yang berhubungan dengan kebangsaan. ${ }^{18}$

Setelah diketahui nilai-nilai pendidikan karakter tersebut, tampak bahwa pendidikan karakter di Indonesia ingin membangun individu yang berdaya guna secara integratif. Hal ini dapat terlihat dalam nilai-nilai yang diusung, yakni meliputi nilai yang berhubungan dengan dimensi ketuhanan, diri sendiri dan juga orang lain.

\section{Perbedaan Pendidikan Akhlak dan Pendidikan Karakter}

Pendidikan Akhlak, mengenai penjelasan akhlak secara luas, banyak sekali tokoh yang memberikan pengertian secara bervariasi. Diantaranya M. Abdullah Darraz, menurut beliau akhlak adalah sesuatu kekuatan dalam kehendak yang mantap, kekuatan dan kehendak mana berkombinasi membawa kecenderungan pada pemilihan pihak yang benar (akhlak yang baik) atau pihak yang jahat (akhlak yang jahat). ${ }^{19}$

Akhlak dipahami oleh banyak pakar dalam arti "kondisi kejiwaan yang menjadikan pemiliknya melakukan sesuatu secara mudah, tidak memaksakan diri, bahkan melakukannya secara otomatis." Apa yang dilakukan bisa merupakan sesuatu yang baik, dan ketika itu ia dinilai memiliki akhlak karimah/mulia/terpuji, dan bisa juga sebaliknya, dan ketika itu ia dinilai menyandang akhlak yang buruk. Baik dan buruk tersebut berdasar nilai-nilai yang dianut oleh masyarakat dimana yang bersangkutan berada.

Bentuk jamak pada kata akhlak mengisyaratkan banyak hal yang dicakup olehnya. Secara garis besar dapat dikatakan bahwa ia bukan saja aktifitas yang berkaitan dengan hubungan antar manusia tetapi juga hubungan manusia dengan Allah, dengan lingkungan. Baik lingkungan maupun bukan, serta hubungan diri manusia secara pribadi. Di samping itu juga perlu diingat bahwa Islam tidak hanya menuntut pemeluknya untuk bersikap baik terhadap pihak lain dalam bentuk lahiriah, sebagaimana yang ditekankan oleh sementara moralis dalam hubungan antarmanusia, tetapi Islam menekankan perlunya sikap lahiriah itu sesuai dengan sikap batiniah.

\footnotetext{
dan pendidikan agama. Keduanya seharusnya dipisahkan dan tidak dicampuradukkan. Baginya, nilai dasar harus dihayati jika masyarakat masih mau hidup dan bekerja secara damai. Nilai-nilai yang seharusnya diprioritaskan dalam pendidikan karakter adalah nilai kebijaksanaan, penghormatan terhadap yang lain, tanggung jawab pribadi, perasaan senasib sependeritaan (public compassion), pemecah konflik secara damai. Lebih lanjut, menurutnya agama bukan menjadi urusan sekolah negeri (public school). Sedangkan pendidikan karakter tidak ada relevansinya dengan ibadah dan doa-doa yang dilakukan dalam lingkungan sekolah. Agama memiliki hubungan vertikal antara sorang pribadi dengan keilahian, sedangkan pola pendidikan karakter adalah horisontal di dalam masyarakat, antara individu satu dengan yang lain. Lihat, Abdul Majid, Pendidikan Karakter Persfektif Islam (Bandung: Remaja Rosdakarya, 2011), 61-62.

${ }^{18}$ Heri Gunawan, Pendidikan Karakter Konsep dan Implementasi. (Bandung: Alfabeta, 2012), 32

${ }^{19}$ Erwin Yudi Prahara, Materi Pendidikan Agama Islam (Ponorogo: STAIN Po Press, 2009), 182.
} 
Pendidikan akhlak sebagaimana dirumuskan oleh Ibn Miskawaih dan dikutip oleh Abudin Nata, merupakan upaya ke arah terwujudnya sikap batin yang mampu mendorong secara spontan lahirnya perbuatan-perbuatan yang bernilai baik dari seseorang. Dalam pendidikan akhlak ini, kreteria benar dan salah untuk menilai perbuatan yang muncul merujuk kepada Al-Qur'an dan Sunah sebagai sumber tertinggi ajaran Islam. Dengan demikian maka pendidikan akhlak bisa dikatakan sebagai pendidikan karakter dalam diskursus pendidikan Islam.

Telaah lebih dalam terhadap konsep akhlak yang telah dirumuskan oleh para tokoh pendidikan Islam masa lalu seperti Ibnu Miskawaih, Al-Qabisi, Ibn Sina, AlGhazali dan Al-Zarnuji, menunjukkan bahwa tujuan puncak pendidikan akhlak adalah terbentuknya karakter positif dalam perilaku anak didik. Karakter positif ini tiada lain adalah penjelmaan sifat-sifat mulia Tuhan dalam kehidupan manusia. ${ }^{20}$

Hadits nabi yang berkaitan dengan konsep pendidikan karakter adalah hadits yang diriwayatkan oleh imam Bukhari-Muslim sebagai berikut :

$$
\begin{aligned}
& \text { قال أسامة بن زيد رضي الله عنهما سمعت رسول الله صلى الله عليه و سلم يقول يُوَْْتَى بِالعآكٍ يَوَمَ }
\end{aligned}
$$

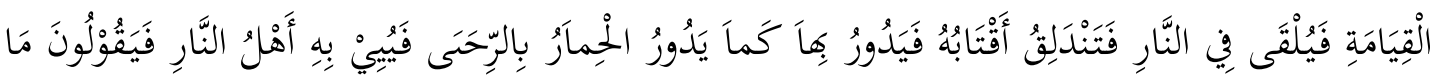

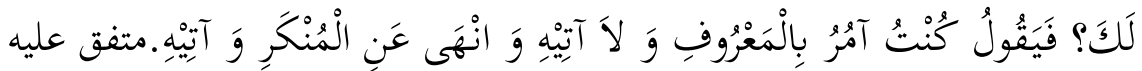

Artinya: "Usamah bin Zaid ra. berkata: Saya mendengar Rasulullah saw. bersabda: Akan dihadapkan orang yang berilmu pada hari kiamat, lalu keluarlah semua isi perutnya, lalu ia berputar-putar dengannya, sebagaimana himar yang ber-putarputar mengelilingi tempat tambatannya. Lalu penghuni neraka disuruh mengelilinginya seraya bertanya: Apakah yang menimpamu? Dia menjawab: Saya pernah menyuruh orang pada kebaikan, tetapi saya sendiri tidak mengerjakan-nya, dan saya mencegah orang dari kejahatan, tetapi saya sendiri yang mengerjakannya”. (Muttafaq Alaih)

Dalam hadits riwayat Bukhori-Muslim di atas menguraikan bahwa pembentukan karakter yang didasari keteladanan akan menuai kebaikan bagi dirinya sendiri dan orang lain.

Dalam Islam sendiri, yang menjadi dasar atau landasan pendidikan akhlak manusia adalah al-Qur'an dan al-Sunnah. Segala sesuatu yang baik menurut alQur'an dan al-Sunnah, itulah yang baik dijadikan pegangan dalam kehidupan seharihari. Sebaliknya, segala sesuatu yang buruk menurut al-Qur'an dan al-Sunnah, berarti tidak baik dan harus dijauhi. ${ }^{21}$

Dalam kaitannya dengan pendidikan akhlak, terlihat bahwa pendidikan karakter mempunyai orientasi yang sama dengan pendidikan akhlak yaitu pembentukan karakter. Perbedaan bahwa pendidikan akhlak terkesan timur dan Islam sedangkan pendidikan karakter terkesan Barat dan sekuler, bukan alas an yang dipertentangkan. Pada kenyataannya keduanya memiliki ruang untuk saling mengisi.

\footnotetext{
20 Siswanto, Perbedaan pendidikan karakter dengan pendidikan akhlak, pendidikan moral, dan pendidikan nilai, http:// siswantozheis.wordpress.com. Diakses tanggal 04 Mei 2016

${ }^{21}$ Rosihan Anwar, Akhlak Tasawuf (Bandung: Pustaka Setia, 2010), 20.
} 
Bahkan Lickona sebagai Bapak Pendidikan Karakter di Amerika justru mengisyaratkan keterkaitan erat antara karakter dengan spiritualitas.

Dengan demikian, bila sejauh ini pendidikan karakter telah berhasil dirumuskan oleh para penggiat sampai pada tahapan yang sangat operasional meliputi metode, strategi, dan teknik, sedangkan pendidikan akhlak sarat dengan informasi kriteria ideal dan sumber karakter baik, maka memadukan keduanya menjadi suatu tawaran yang sangat inspiratif. Hal ini menjadi entry point bahwa pendidikan karakter memiliki ikatan yang kuat dalam nilai-nilai spiritualitas dan agama $^{22}$

Pendidikan karakter yang berbasis Al Qur'an dan Assunnah, gabungan antara keduanya yaitu menanamkan karakter tertentu sekaligus memberi benih agar peserta didik mampu menumbuhkan karakter khasnya pada saat menjalani kehidupannya. Hanya menjalani sejumlah gagasan atau model karakter saja tidak akan membuat peserta didik menjadi manusia kreatif yang tahu bagaimana menghadapi perubahan zaman, sebaliknya membiarkan sedari awal agar peserta didik mengembangkan nilai pada dirinya tidak akan berhasil mengingat peserta didik tidak sedari awal menyadari kebaikan dirinya. ${ }^{23}$

Melalui gabungan dua paradigma ini, pendidikan karakter akan bisa terlihat dan berhasil bila kemudian seorang peserta didik tidak akan hanya memahami pendidikan nilai sebagai sebuah bentuk pengetahuan, namun juga menjadikannya sebagai bagian dari hidup dan secara sadar hidup berdasar pada nilai tersebut.

\section{Pendidikan Karakter menurut Imam Ibnu Qoyyin Al Jauziyah}

Nama lengkapnya Muhammad bin Abi Bakr bin Ayyub bin Sa'ad bin Haris Az-Zar'I Ad-Damasqy. Laqab-nya adalah Syamsudin. Kunyahnya adalah Abu Abdillah. Beliau lebih terkenal dengan panggilan Ibnu Qayyim Al-Jauziyyah. ${ }^{24}$ Beliau adalah putra seorang ulama pendiri Madrasah "Al-Jauziat " (Qayyim AlJauziat) di Damaskus. Dari situlah beliau terkenal dengan sebutan Ibnu Qayyim AlJauziat. ${ }^{25}$

Al-Jauziyyah adalah nama sebuah sekolah di Damaskus, yang diambil dari nama pendirinya, yaitu Muhyiddin Abu Mahasin Yusuf bin 'Abdurrahman bin 'Ali bin al-Jauzi. Beliau wafat pada tahun $656 \mathrm{H}$. Madrasah al-Jauziyyah selesai dibangun pada tahun $652 \mathrm{H}$, dan sekarang menjadi kompleks perdagangan. Di atasnya terdapat sebuah masjid kecil untuk shalat berjamaah bagi penghuni dan pengunjung pasar alBazuriyah saat ini. Ayah beliau bernama Abu Bakar. Dia menduduki posisi yang sangat penting, sebagai pengatur dan penanggung jawab kompleks tersebut, yang mencakup masalah perlengkapan, penyiraman taman, kebersihan, service lampu dan sebagainya. Ayah Ibnu Qayyim adalah seorang yang rajin beribadah dan tidak banyak bicara. Beliau wafat pada bulan Dzulhijjah tahun $723 \mathrm{H}$. dan beliau mempunyai andil besar dalam ilmu faraidh, yaitu ilmu pembagian harta warisan. ${ }^{26}$

\footnotetext{
${ }^{22}$ Marfu', Perbedaan pendidikan karakter dengan pendidikan akhlak, pendidikan moral, dan pendidikan nilai, http:// risetpendidikangmarfu'.com, Diakses pada tanggal 20 Mei 2014.

${ }^{23}$ Ni'matulloh.et. all, Pendidikan Karakter Dalam Persfektif Pendidikan Islam, (http://nimatlloh. blogspot.com, diakses pada tanggal 20 Mei 2014)

${ }^{24}$ Hasan bin Ali Hasan Al-Hijazy, Manhaj Tarbiyah Ibnu Qayyim, Teremahan Muzaidi Hasbullah, (Jakarta : Al-Kautsar, 2001), h.1.

${ }^{25}$ A. Susanto M.Pd., Pemikiran Pendidikan Islam, (Jakarta : Amzah, 2009), h.32.

26 Ibnu Qayyim Al-Jauziyyah, Al-Jawab Al-Kafi: Mengetuk Pintu Ampunan Meraih Berjuta Anugerah, terjemahan Futuhal Arifin, ( Jakarta : Gema Madinah Makkah Pustaka, 2007), h.395.
} 
Ibnu Qayyim Al-Jauziyyah dilahirkan pada tanggal 7 Shafar $691 \mathrm{H}$ atau 4 februari 1292 M di sebuah desa pertanian yang disebut Hauran. Desa ini berada sekitar 55 mil, sebelah tenggara kota Damaskus, Suriah. Kemudian ia merantau ke Damaskus untuk mencari ilmu di sana. ${ }^{27}$

Ibnu Qayyim adalah murabbi yang mulia, telah bekerja di medan tarbiyah dengan seluruh tenaga dan ilmunya. Mak tak heran jika murid-muridnya tersebar dimana-mana. Dan muridnya yang paling terkenal adalah Ibnu Katsir (pengarang Kitab Al-Bidayah wan Nihayah), kemudian Ibnu Rajab (pengarang kitab Ad-Dhail Al-Madzahibil Hanabilah), kemudian Ibnu Abdul Hadi dan anaknya yang bernama Abdullah. Juga termasuk murid beliau adalah Syamsuddin Muhammad bin Abdul Qadir An-Nabilisy ( pengarang kitab Mukhtasar Thabaqat Hanabilah). ${ }^{28}$

Ibnu Qayyim wafat di Damaskus pada 13 Rajab tahun 751 H/1350 M, sepertiga terakhir malam Kamis. Jamaah yang datang untuk berta'ziyah sangat banyak, sehingga prosesi shalat jenazah dimulai dari pagi hingga menjelang Zuhur di masjid Jami' Jarrah. Beliau dimakamkan di pemakaman al-Bab alShaghir dengan diiringi oleh ribuan orang pengantar jenazah. Banyak orang yang bermimpi beliau dengan mimpi yang baik. Saat menjelang wafat, beliau bercerita bermimpi bertemu dengan Syaikh Ibnu Taimiyah (gurunya). Dia bertanya tentang tempat gurunya di alam kubur, maka Ibnu Taimiyah menjawab bahwa dirinya ditempatkan pada derajat seperti si fulan, dia menyebutkan nama beberapa orang besar, seraya mengatakan, "Engkau hampir bergabung dengan mereka, akan tetapi engkau berada dalam satu tingkatan bersama dengan Ibnu Khuzaimah." Makam Ibnu Qayyim dikenal hingga sekarang. Letaknya di samping Madrasah alShabuniyah disisi kiri jalan masuk menuju pemakamn al-Bab as-Shaghir dari arah pintu baru yang diperluas sejak 40 tahun yang lalu. ${ }^{29}$

Menurut Ibnu Qoyyim, pendidikan secara bahasa diambil dari kata tarbiyah yang memiliki arti merawat, menumbuhkan, mendidik, memimpin, memiliki, memperbaiki, dan menguatkan. Kemudian dari kata ar rabb yang bermakna memiliki, majikan, guru, pendidik,yang menegakkan, yang memberi nikmat, yang memberi nikmat, yang mengurus dan yang memperbaiki. Kemudian diambil dari kata ar rabbany yaitu 'alim yang mengajar, yang memberi pengetahuan dan ilmu yang besar manfa'atnya. ${ }^{30}$

Dengan demikian pendidikan merupakan bimbingan urusan anak dan membinanya dengan baik, merawat dan menjaganya dengan gizi dan mengarahkannya hingga meninggalkan masa kanak-kanak, menjaga masa-masa selanjutnya dengan mengarakan dengan pendidikan secara beransur, membimbing urusan mereka dan menyiasati urusan mereka untuk kemashlahatan dirinya, begitu pula memperhatikan urusannya dan menumbuh kembangkan sehingga mencapai kesempurnaan sampai dia bisa mengajark manusia yang lain tumbuh beransur bersama mereka dari mulai permasalahan yang kecil sampai yang besar. Dan

\footnotetext{
${ }^{27}$ Ibnu Qayyim Al-Jauziyyah, Kunci Surga: Mencari Kebahagiaan Dengan Ilmu, terjemahan Abdul Matin dan Salim Rusydi Cahyono, ( Solo : Tiga Serangkai, 2009), 707.

${ }^{28}$ Hasan bin Ali Hasan Al-Hijazy, Manhaj Tarbiyah Ibnu Qayyim, Terjemahan Muzaidi Hasbullah,( Jakarta : Al-Kautsar, 2001), h.11.

${ }^{29}$ Ibnu Qayyim Al-Jauziyyah, Al-Jawab Al-Kafi: Mengetuk Pintu Ampunan Meraih Berjuta Anugerah, terjemahan Futuhal Arifin, ( Jakarta : Gema Madinah Makkah Pustaka, 2007), h.405-406

${ }^{30}$ Hasan bi Ali al Hijazi, Al Fikru At Tarbawi 'inda Ibnil Qoyyim, 1988, Daar al Hafidz, hal. 156
} 
selajutnya Ibnu Qoyyim menjelaskan bahwa pendidikan merupakan tanggung jawab guru, orang tua dan pemerintah.

Pendidikan karakter secara spesifik mengarah kepada pembentukan akhlak, kepribadian, etika, dan prilaku. Dan pendidikan akhlak itu erat kaitannya dengan jiwa seseorang. Ibnu Qoyyim bependapat ${ }^{31}$ bahwa permasalahan ada dalam jiwa, dan mengetahui jiwa merupakan jalan yang lurus untuk mendapatkan akhlak yang mulia dan setiap individu harus mengetahui apa-apa yang akan membersihkan jiwanya supaya beruntung dan apa-apa yang mengotorinya sehingga merugi. Keadaan jiwa manusia itu tercipta dari sesuatu dan ia memiliki bentuk tertentu, karakteristik, kekhususan-kekhususan dan kebutuhannya. Dan Islam memelihara hukum-hukum dan tujuan syari'atnya terhadap hal itu, maka memberi bagi badan kebutuhankebutuhannya dan membimbing tuntutan-tuntutannya sesuai dengan aturan tertentu, begitu pula memberi kepada jiwa apa-apa yag dibutuhkannya untuk meninggikan derajatnya menuju kesempurnaan manusia,

Pendidikan Menurut Ibnu Qoyyin tersebut tidak jauh dari definisi secara etimologi dan termininologi. Pendidikan menurutnya menyangkut pendidikan hati, pendidikan badan secara berbarengan,kemudian dijelaskan bagaimana mendidik masing-masing (hati dan badan), beliau berkata : "masing-masing dari hati dan badan membutuhkan pendidikan agar supaya tumbuh dan berkembang sehinggga sempurna dan baik, maka seperti halnya badan butuh pertumbuhan dengan gizi yang memperbaikinya dan penjagaan dari hal-hal yang membahayakan, begitu pula hatitidak akan bersih berkembang dan sempurna kecuali dengan hal tersebut, dan tidak ada jalan untuk sampai padanya kecuali dengan al Quran, sekalipun sampai kepada sesuatu tanpa al Quran itu hanya sedikit saja, tidak sampai kepada kesempurnaan yang di maksud. ${ }^{32}$

Dari uraian di atas dapat diambil faedah bahwa pendidikan mengandung dua aspek, pertama : yang berkaitan dengan ilmu pendidik dimana membimbing dengan ilmunya maka ia menyempurnakannya, menjaga dan merawatnya seperti menjaga pemlik harta terhadap hartanya. Kedua : mendidik manusia dengan ilmu ini dan beransur bersama mereka seperti mendidiknya orang tua terhadap anaknya. Adapun makna yang pertama adalah pendengaran, kedua akal dan pemahaman, ketiga merawat dan menjaganya, keempat menyampaikan dan mengajarkannya. Menyebarkan di antara manusia merupakan fakto yang kuat untuk menambah ilmu, memelihara dan menjaganya, dan supaya tidak hilang dan menyembunyikannya.

Tujuan pendidikan menurut Ibnu Qoyyim menumbuhkembangkan seluruh potensi anak, memelihara fitrah, dan menganya dari penyimpangan serat merealisasikan arti ibadah kepada Allah SWT. Karena hal ini sesuai dengan Allah menciptakan mannusia " Dia menciptakan manusia agar beribadah kepada-Nya dan itu tujuan adalah tujuan utama dari mereka. ${ }^{33}$ Dalam hai ini sebagai perwujudan dari fiman-Nya : "Dan aku tidak menciptakan jin dan manusia melainkan supaya merekamengabdi kepada-Ku”. QS. Ad Dariyat : 56

Di antara tujuan pendidikan karakter menurut pakar pendidikan ini menanamkan akhlak yang mulia, dan memerangi akhlak yang jelek, mewujudkan kebahagian bagi anak yang sedang tumbuh, dan memperhatikan ketika ia bicara,

\footnotetext{
${ }^{31}$ Rukyah Toha al Jabir, Tajkiyatu an Nafsi, Qaira Mesir, Daar at Taqwa, 1428 H, hal. 10

32 Ibnu Qoyyim, Ighastatu al Lahfan min Musyayidi as Syaithon, Baerut, 1984, Daarul Fikr, juz 1 hal. 46

${ }^{33}$ Ibnu Qoyyim, Miftah Dar al Sa'adah, baerut, 1983, Daarul Fikr, Juz 1 hal. 5
} 
tidur dan bergaul dan mengarahkannya dalam hal itu memperhatikan pakaian dan tidak memperbolehkan memakai pakaian yang diharamkan, serta menumbuhkan bakatnya dan mengarahkannya. Konsen terhadap pendidikan agama dan menjadikannya sebagai pendidikan pokok. Hal tersebut dijelaskan dalam urainya tentang pengarahan prilaku anak dengan mengatakan kepada orang tua dan pendidiknya : “. . kalau orang tua melihat berbeda, bahwa anak itu tercipta bukan untuk hal itu, kemudian dengan mata terbuka anak punya kecenderungan terhadap suatu produksi da dia memiliki kesiapan untuk itu, menerimanya dan itu produksi yang midah dan bermanfaat bagi manusia, dan hendaklah dia didukung setelah diajarkan apa yang dibutuhkan dalam urusan agamanya. ${ }^{34}$

Menurut Ibnu Qoyim Secara global ahdaf (tujuan) dan sasaran pendidikan karakter adalah :

a. Ahdaf Jismiyah ( tujuan yang berkaitan dengan badan)

Maksudnya diadakan tarbiyah adalah untuk menjaga kesehatan badan anak didik, sebagaimana yang diwasiatkan oleh Ibnu Qayyim Rahimahullah kepada orang tua." Hendaklah bayi yang baru dilahirkan itu disusukan kepada orang lain, karena air susu ibu di hari pertama melahirkan sampai hari ketiga masih bercampur dan kurang bersih serta masih terlalu kasar bagi sang bayi yang hal ini akan membahayakan sang bayi. ${ }^{35}$

Termasuk dari ahdaf jismiyah yang hendak diwujudkan oleh kerja tarbiyah adalah selalu memperhatikan anak dan mengawasinya dalam hal makan dan minumnya, sebagiman yang diwasiatkan oleh Ibnu Qayyim Rahimullah berikut ini :

"Hendaklah para orang tua itu tidak membiarkan anak-anaknya mengkonsumsi makanan dan minuman yang berlebihan, hal itu demi menjaga terbentuknya pencernaannya dan keteraturan cara kerjanya, yang sudah diketahui bahwa sehatnya badan itu tergantung pada tepatnya (teraturnya) kerja pencernaan tersebut. Dengan tidak terlalu banyak mengkonsumsi makanan dan minuman akan mengurangi penyakit, karena dalam tubuh tidak terdapat timbunan sisa-sisa makanan. ${ }^{36}$

b. Ahdaf Akhlakiyah (tujuan yang berkaitan dengan pembinaan akhlak)

Menurut Ibnu Qayyim Rahimullah, kebahgiaan akan bisa diraih dengan terhiasinya diri dengan akhlak mulia dan terjauhkannya dari akhlak buruk. Oleh karena itu beliau sangat wanti-wanti menasehati para murabbi (pendidik) agar tidak memberi kesempatan kepada anak didiknya untuk berkhianat dan berbohong, sebab khianat dan kebohongan akan merusak bangunan kebahagiaan jiwanya, sebagaimana pernyataan beliau kepada orang tua berikut ini. ${ }^{37}$

"Jika sekali saja terbuka kesempatan bagi seorang anak untuk berbuat bohong dan khianat, maka akan hancurlah kebahagiaannya, baik di dunia maupun di akhirat, dan anak tersebut akan terhalangi untuk mendapatkan seluruh kebaikan yang semestinya dapat diraihnya, jika ia tidak berbohong dan berkhianat."

c. Ahdaf Fikriyah (tujuan yang berkaitan dengan pembinaan akal)

\footnotetext{
${ }^{34}$ Ibnu Qoyyim, Tuhfatu al Maudud bi al Ahkamil Maulud, Mesir, Darr Ibnu Rajab,1999, hal 244

${ }^{35}$ Ibnu Qayyim Al-Jauziyah, Tuhfatul Maudud Bi Akmamil Maulud: Bingkisan Kasih Untuk si Buah Hati, terjemahan Abu Umar Basyir al-Maedani, (Solo: Pustaka Arafah, 2006), h.84.

${ }^{36}$ Ibnu Qayyim Al-Jauziyah, Miftah Darus Sa'adah: Kunci Surga Mencari Kebahagiaan dengan Ilmu, h 5

${ }^{37}$ Ibnu Qayyim Al-Jauziyah, Tuhfatul Maudud Bi Akmamil Maulud. H 145
} 
Tarbiyah yang baik ialah yang bertujuan untuk membina dan menjaga anak dan pemikiran anak didiknya. Ibnu Qayyim Rahimullah menyebutkan masalah ini dalam sebuah pernyataan berikut ini. ${ }^{38}$ "Yang perlu diperhatikan oleh para murabbi adalah agar mereka sama sekali tidak memberi kesempatan kepada anak didiknya untuk berinteraksi dengan sesuatu yang membahayakan dan merusak akalnya, seperti; minum-minuma yang memabukkan atau narkoba, dan hendaknya anak didik dijauhkan dari pergaulan denganorang-orang yang dikhawatirkan akan merusak jiwanya, dan dijauhkan dari melakukan pembicaraan dan memegang sesuatu yang akan merusak jiwanya, sebab semua itu akan menjatuhkannya ke lembah kehancuran."

Ketahuilah, jika sekali saja terbuka kesempatan bagi sang anak untuk melakukan perbuatan tersebut, maka akan terbiasa melakukan perbuatan yang hina dan kotor (seperti; zina, mucikari, dan sebagainya), padahal tidaka akan masuk surga orangorang yang berbuat zina. ${ }^{39}$

d. Ahdaf Maslakiyah (tujuan yang berkaitan dengan skill)

Dalam pandangan Ibnu Qayyim Rahimullah, tarbiyah harus memiliki tujuan menyingkap bakat dan keahlian (skill) yang tersimpan dalam diri seorang anak. Kemudian setelah diketahui bakat anak didiknya, maka segera diadakan pembinaan dan pengarahan kepada bidang-bidang yang sesuai dan baik yang akan mewujudkan kemaslahatan diri dan umat manusia secara keseluruhan.

Apa yang menjadi pemikiran beliau ini bisa kita lihat dalam sebuah pernyataanya berikut ini, beliau berkata, "Di antara hal yang seharusnya diperhatikan adalah potensi dan bakat yang dimiliki oleh masing-masing anak. Sebab ia dilahirkan dengan membawa bakat masing-masing. Asal jangan menggiring anak kepada sesuatu yang diharamkan syariat. Jika anak dipaksa melakukan atau menekuni sesuatu yang tidak menjadi bakat atau kecenderungannya, maka ia tidak akan berhasil, bahkan bias kehilangan bakatnya ${ }^{40}$

\section{Dimensi Pendidikan Karakter Menurut Imam Ibnu Qoyyim}

Konfigurasi karakter dalam konteks totalitasnya, sama dengan tujuan dan sasaran pendidikan Islam yaitu membangun seluruh potensi yang dimiliki manusia supaya menjadi manusia seutuhnya, yang sasaran pendidikannya mencakup sembilan aspek pendidikan seperti diungkapkan Ibnu Qoyyim : "menumbuh kembangkan peserta didik sehingga mencapai kesempurnaan yang layak dalam berbagai segi yaitu : rohani, keimanan, fikiran, etika (akhlak), kemasyarakatan, kehendak, jasmani, perasaan, dan sexual agar dia hidup bahagia didunia dan akhiratnya dan berguru dalam kehidupan di lingkungan masyarakatnya",41

Hal tersebut di atas hampir sejalan dengan ruang lingkup pendidikan karakter yang digariskan oleh undang-undang sisdiknas 2010 yang mencakup empat aspek pengolahan yaitu : olah pikir, olah hati, olah raga dan olah rasa dan karsa, hanyasannya paparan Ibnu Qoyyim lebih rinci dan menyeluruh dan diungkapkan

\footnotetext{
${ }^{38}$ Ibid h 146

${ }^{39}$ Hasan bin Ali Hasan Al-Hijazy, Manhaj Tarbiyah Ibnu Qayyim, terjemahan Muzaidi Hasbullah, (Jakarta: Al-Kautsar, 2001), h.87.

40 Ibnu Qayyim Al-Jauziyah, Tuhfatul Maudud Bi Akmamil Maulud: Bingkisan Kasih Untuk si Buah Hati, terjemahan Abu Umar Basyir al-Maedani, (Solo: Pustaka Arafah, 2006), h.147.

${ }^{41}$ Hasan bi Ali al Hijazi, Al Fikru At Tarbawi 'inda Ibnil Qoyyim, hal. 19
} 
dengan sembilan aspek pendidikan Islam dalam membentuk karakter yang seimbang menyeluruhnya terhadap semua potensi yang ada pada manusia, antara lain :

\section{a. Pendidikan Karakter Keimanan}

Pendidikan karakter yang paling utama diawali dengan pemahaman seseorang terhadap nilai-nilai keimanan, karena ia merupakan landasan utama yang akan memberikan arahan dalam kehidupannya, membentuk kepribadiannya yang lurus dan bersih. Kecintaan terhadap Allah dan Rasul-Nya termasuk hal pokok dalam hal pendidikan karakter, tidak boleh dinomor duakan sesuai dengan urutannya dalam rukun Islam yang pertama yaitu dua kalimat syahadat.

Apabila mempelajari sejarah Rasulullah dalam mendidik para shahabat r.a pada priode Makkah dan sesudahnya, niscaya akan mendapati bahwa perhatian Rasulullah tercurahkan kepada pendidikan keimanan, dan membangun aqidah dalam diri mereka sebelum terhadap segi pendidikan lainnya.

Sesungguhnya wahyu yang diturunkan kepadanya membicarakan hal penting yaitu masalah keimanan kepada Allah swt dengan menggunakan berbagai cara antara lain lewat peringatan akam kekuasaan Allah swt dalam jiwa dan alam raya, dan peringatan adanya alam akhir, hari kebangkitan. Dibangkitkan dialam kubur, dsn menyebuitkan kisah umat terdahulu dan apa-apa yang menimpa mereka disebabkan membohongkan Nabi mereka dengan adzab dengan dihancurkan dan dibinasakan serta diperingatkan dengan nampaknya kematian dan kehidupan. Hal ini menjadi pengat terhadap keimanan, maka menjadi pengawas serata pengawas terhadap dirinya. Dan menegaskan tidak ada seorangpun yang lepas dari pengawasannya, kapan pun dan dimanapun berada, Firman-Nya : "Tidakkah kamu perhatikan, bahwa sesungguhnya Allah mengetahui apa yang ada di langit dan di bumi? Tiada pembicaraan rahasia antara tiga orang, melainkan Dialah keempatnya. Dan tiada (pembicaraan antara) lima orang, melainkan Dialah keenamnya. Dan tiada (pula) pembicaraan antara jumlah yang kurang dari itu atau lebih banyak, melainkan Dia berada bersama mereka di manapun mereka berada. Kemudian Dia akan memberitahukan kepada mereka pada hari kiamat apa yang telah mereka kerjakan. Sesungguhnya Allah Maha mengetahui segala sesuatu" QS. Al Mujadah : 7

Selama priode Makkah 13 tahun lamanya kandungan ayat al Quran selalu berisi tentang ajaran keimanan, hal ini menujukkan betapa penting keimanan itu, kemudian priode madaniyah wahyupun tidak melupakan hal keimanan bahkan menjadikan dasar dan pokok, atau tujuan hukum dan syariat, umpamanya Allah mewajibkan shaum, Dia mengaitkan dengan iman dengan panggilannya dan taqwa sebagai targetnya.

Ibnu Qoyyim berpendapat bahwa tidak akan terlihat kesempurnaan iman seseorang kecuali dengan hal yaitu cinta, benci, pemberian, penolakan. Apabila ada hal itusemua dengan lillah dan fillah, maka iman itu pada derajat yang sempurna yang tinggi, maka Beliau berkata : "iman itu adalh ilmu dan amal, dan amal itu buah dari ilmu, dan amal itu ada dua macam : amal hati yaitu cinta dan benci dan berakibat pada keduanya pekerjaan anggota badan mengerjakan dan meningggalkan yaitu memberi dan menolak. Dan apabila ada yang empat ini 
dengan karena Allah maka pelakunya sempurna iman, dan jika kurang maka dengan tidak lillah maka kuranglah imannya"42

Seseorang yang tershibghoh jiwanya dengan pendidikan keimanan, maka akan melahirkan karakter yang menjadikannya melaksanakan perintah Allah,mengikuti petunjuk Rasulullah saw. Imam Ibnu Qoyyim mengatakan mengikuti petunjuk itu dengan dua hal : " mengikuti petujuk Allah itu membenarkan beritanya tanpa tercemar subhat yang tercela dalam membenarkannya, dan melakukan perintahnya tanpa tercemar dengan syahwat yang menghalangi untuk melakukan perintahnya"43

\section{b. Pendidikan Karakter Ruhani}

Manusia adalah ungkapan dari kumpulan ruh, badan dan akal. Maka pendidikan yang seimbang dengan memperhatikan kebutuhan perkembangan semua unsur ini secara seimbang tidak cenderung kepada satu bagian dan melupakan sisi lainnya.

konkritnya badan bisa dijelaskan karena terjangkau oleh indra dan dapat diterangkan karena badan disifati tinggi, pendenk, besar, kecil dan sebagainya, akan tetapi lain halnya dengan ruh. Imam Ibnu Qoyyim memberikan definisi ruh sebelum pakar pendidikan yang lain memberikan definisi tentangnya, beliau mengatakan: "bentuk yang berbeda dengan esensinya dengan bentuk yang tersentuh, yaitu subtansi cahaya yang tinggi dan ringan yang bergerak menembus inti anggota, berjalan seperti berjalannya air dari sumbernya, dan berjalannya minyak dalam zaitun, api dalam arang selama anggota tubuh itu layak untuk menerima pengaruh-pengaruh yang melimpah atasnya dari subtansi yang halus ini tetaplah bentuk halus itu sebagai jaringan pada anggota ini, dan memberikan faedah pengaruh-pengaruh itu terhadap anggota tersebut dari perasaan, gerakan dan kehendak." 44

Ruh memiliki sifat-sifat tertentu imam Ibnu Qoyyim mengatakan ${ }^{45}$ “ terdapat nash-nash yang jelas dan shohih yang menunjukkan bahwa ruh itu naik dan turun, digenggam dipegang dan dilepaskan dan dibuka baginya pintu langit, bersujud dan berbicara dan ia keluar dan mengalir seperti mengalirnya percikkan air dikafani dan dipelihara dengan kafan surga dan neraka dan sesungguhnya malaikat maut mengambilnya dengan tangannya, dan mencium padanya seakan lebih harus dari misk atau bau dari bangke, dan digiring dari langit kelangit kemudian dikembalikan ke bumi bersama malaikat, dan sesungguhnya jika ia keluar diikuti oleh mata sekira melihatnya diwaktu ia keluar, dan al Quran menjukan ia berpindah-pindah dari satu tempat ketempat yang lain sampai pada kerongkongan pada gerakkannya"

Sifat dan keadaan tersebut tidak bisa dilihat manusia, tapi mereka bisa disaksikan bekas-bekas hal itu pada badan. Jika ruh itu baik, soleh dan taqwa, nampak itu pada amal-amal yang baik dalam perkataan manusia dan perbuatannya, tapi jika jelek keluar dari orang itu segalla kekejian dan kejelekan

\footnotetext{
42 Ibnu Qoyyim, Ighastatu al Lahfan min Musyayidi as Syaithon, Baerut, 1984, Daarul Fikr, juz 2 hal. 124

${ }^{43}$ Ibnu Qayyim Al-Jauziyah, Miftah Darus Sa'adah: Kunci Surga Mencari Kebahagiaan dengan Ilmu, $\mathrm{h}$ 40

${ }^{44}$ Ibnu Qoyyim, Ar Ruh, 1991, Bairut, lebanon, Daar al Fikr, hal. 178

${ }^{45}$ Ibnu Qoyyim, Ar Ruh,..h 111
} 
dan perbuatan bejad dan keji. Pendidikan ruh itu memastikan kebaikan dan keistiqomahannya supaya keluar darinya perbuatan-perbuatan yang baik.

Imam Ibnu Qoyyim mengatakan jiwa itu adalah ruh dari segi zatnya, tapi berbeda dengan sifatnya, oleh karenanya jiwa disifati dengan muthmainnah, atau amaroh, atau lawwamah mulawwamah, atau lawwamah ghair mulawwamah. Beliau berkata : ${ }^{46}$ "adapun perbedaan antara jiwa dan ruh pada sifatbukan pada dzat" artinya keduanya satu ditinjau pada dzatnya, dan tiga ditinjau pada sifatnya. Banyak kelompok yang menyatakan bahwa ruh dan jiwa itu berbeda, dia memberikan komentar ${ }^{47}$ " adapun ruh yang meninggal dan ditangkap adalah satu ruh, yaitu jiwa"

Kesehatan roh dan keselamatannya itu berdiri di atas terlepasnya perasaan itu dari perasaaan cemas, gelisah, gundah, bingung, susah, sedih. Ketika ia lepas dari penyakit-penyakit itu, maka ia dalam keadaan aman, senang dan tentram, bahagia, girang dan gembira. Dan ini tidakl akan terwujud kecuali dengan iman kepada Allah, percaya dengan apa yang ada padanya hal ini yang akan membuat jiwa sempurna.

Dengan demikian Imam Ibnu Qoyyim mengatakan 48 "Bahwa ketenangan dan ketentraman hati, dan kemantapannya dengan hilangnya gelisah, gundah dan kebingungan, hal ini tidak akan terwujud dengan sesuatu kecuali dengan Allah dan mengingatnya"

Kegelisahan itu akan tetap ada sehingga hati dimasuki keimanan terhadap asma dan sifat-Nya. Dan akan menambah ketentraman bila mendengar bacaan ayat-ayat Allah SWT yang mengandung salah satu sifat dan asma Allahb SWT, dan ini termasuk pokok keimanan, dan akhirnya terasa tentram setiap berita yang diterimanya.

Penyakit ruh lebih berbahaya kepada manusia, dan lebih besar madhorotnya dan lebih membinasakan dari pada penyakit badan. Dan pennyakit ruh menurut Ibnu Qoyyim bermacam-macam, diantaranya : penyakit syahwat, penyakit Syubhat, lalai pada tempat kembali yang pasti kelalaian ini yang mengakibatkan perbuatan dosa dan lain sebagainya.

Lalai merupakan penyakit roh, dan pengobatannya seperti dinyatakan Imam Ibnu Qoyyim dengan waspada, begitu juga dari berbagai penyakit roh yang lain seperti : ragu, khiyanat, riya, bohong, lemah, tinggi hati, sombong, malas dan yang lainnya. Selanjutnya Imam Ibnu Qoyyim mengatakan ${ }^{49}$ : “ jika diselumuti dengan keraguan maka menuju kepada yakin, dari kebodohan kepada ilmu, dari lalai kepada ingat, dari khiyanat kepada taubat, dari riya kepada ikhlas, dari bohong kepada jujur, dari lemah kepada pintar, dari kekuatan ujub kepada hinanya ketundukan dari sesat kepada rawadhdhu. Sumber dari itu semua kebangkitan dengan waspada"

Pendidikan yang benar adalah pendidikan yang merealisasikan keseimbangan pada kehidupan seseorang, maka diberikan pada setiap sisi pendidikannya sesuatu yang bisa menyampaikan kepada kesempurnaan supaya bisa mengerjakan keajiban dan tanggung jawabnya dengan sebaik-baiknya. Dan ruh itu unsur terpenting yang ada pada manusia dan dia tidak akan sempurna

\footnotetext{
${ }^{46}$ Ibnu Qoyyim, Ar Ruh,..h 217

${ }^{47}$ Ibnu Qoyyim, Ar Ruh,..h 219

${ }^{48}$ Ibnu Qoyyim, Ar Ruh,..h 221

${ }^{49}$ Ibnu Qoyyim, Ar Ruh,..h 221
} 
kecuali dengan pendidikan yang dimbil dari manhaj Allah SWT dan kehilangan kesmpurnaa ruh berbeda dengan kehilangan unsur aapun dari anggota. Kehilangan kesempurnaan adalah kerusakan bagi seseorang dan kesia-siaan baginya.

Menurut Imam Ibnu Qoyyim ${ }^{50}$ pendidikan ruh itu terdiri dari : pendidikan dengan ma'rifat kepada Allah, memperdalam keimanan terhadap apa yang diberikan Allah, pendidikan dan latihan membiasakan amal kebaikan, menghadapkan diri kepada Allah dan disibukkan dengan hal-hal yang diridhiNya, kesempurnaan roh pada ilmu dan irodah serta mahabbah dan muhasabah jiwa sebelum tidur setiap malam.

\section{c. Pendidikan karakter pikiran}

Allah SWT telah memulyakan manusia di atas semua makhluknya sesuai dengan apa yang telah dianugrahkannya dari sifat-sifat keutamaan berupa bentuk yang sempurna dan sifat-sifat akhlakiyah, diantaranya akal yang memastikan ia mampu menanggung beban-beban, yang dengannya bisa mendapatkan ilmu, dan menjangkau ma'rifat, yang dengannya pula berhak mendapat kemuliaan.

Imam Ibnu Qoyyim memberi komentar tentang pentingnya menggunakan akal, beliau mengatakan " sesungguhnya Allah telah memuji akal dan pemiliknya di dalam kitab-Nya dan di dalam banyak tempat, dan Ia mencela orang yang tidak ada akalnya dan Ia mengkhabarkan bahwa mereka itu ahli neraka yang memiliki pendengaran dan tidak berakal"

Akal adalah mesin penggerak bagi seluruh badan, maka baiknya badan adalah baiknya akal, begitu juga hilangnya. Dia bependapat ${ }^{52}$ terkadang dikatakan bahwa akal itu raja, sedangkan badan rohnya, indranya, dan gerakkannya, semua adalah masyarakatnya"

Pemikiran adalah menghadirkan dua pengetahuan dalam hati agar berbuah darinya pengetahuan ketiga. ${ }^{53}$ Sedngkan arti tafakkur adalah hati mencari sesuatu yang belum didapatkan dari ilmu-ilmu dari sesuatu yang ia telah mendapatkannya. Dan fikr (ide) adalah menggunakan akal pada hal-hal yang sudah duketahui untuk sampai kepada hal yang majhul (belum diketahui.

Pendidikan pemikiran menurut Imam Ibnu Qoyyim ${ }^{54}$ adalah ajakan untuk memperhatikan ciptaan Allah SWT, ajakan untuk memperhatikan ayat-ayat Allah yang dibaca, melakukan perintah Allah, istiqomah pada manhajnya, waspada dengan bahaya maksiat, taqlid (mengikuti pekerjaan orang sementara dia tidak tahu argumentasinya) hal ini akan mengosongkan berpikir dan pendidikan pikiran tentramnya badan dari kesibukan-kesibukan yang memganggu berpikir.

\section{d. Pendidikan karakter perasaan}

Pendidikan perasaan merupakan pendidikan yang tidak bisa di abaikan, malahan sangat penting sekali terutama pada zaman sekarang banyak sekali penyakit psikologis yang menimpa akibat stres menghadapai kehidupan zaman modern dengan segala macam problemanya yang semakin serat dengan persaingat ketat dan kompetitif di berbagai lapangan kehidupan. Oleh karenanya pendidikan di bidang 'athifiyah menyangkut permasalahan psikologis sangat urgen di ajarkan.

\footnotetext{
${ }^{50}$ Ibnu Qayyim Al-Jauziyah, Miftah Darus Sa'adah, h. 124

${ }^{51}$ Ibid 363

52 Ibid 174

${ }^{53}$ Ibnu Qayyim Al-Jauziyah, Miftah Darus Sa'adah, h. 181

${ }^{54}$ Ibid h 201
} 
Manusia memiliki naluri seperti yang di ungkapkan Muhammad Amin dalam Hasan Ali Al Hijazi " naluri itu keadaanya lebih sempurna dan lebih dekat untuk melakukan kebutuhan-kebutuhannya dengan mudah dan enteng. Naluri itu tidak ditemukan bentuknya yang asli kecuali pada anak-anak dan manusia primitive. Adapun pada yang lainnya ia mencopot fitrahnya dan menampakkan dalam bentuk yang lain. Adapun naluri pada manusia menjadi lurus dan pelurusan itu menjangkau terhadap pengaruh naluri atau prilaku yang tumbuh". 55

Jadi naluri itu lebih nampak pada orang primitive atau hewan ang tidk berkal, sementara pada manusia, naluri itu tertutupi dengan ilmu dan akhlaknya, sekalipun pada dasarnya memiliki kecenderungan terhadap naluri itu karena merupakan sifat dasar yang dibawa manusia sejak lahir (sifat-sifat kemanusiaan).

Menurut Imam Ibnu Qoyyim ${ }^{56}$ sifat-sifat kemanusia memilki pengaruh kepada perkataan, baik mengungkapkan, mempertimbangkan, melakukan dan membatalkan. Hal ini seperti datangnya sifat lupa, salah, terpaksa, mabuk, gila, takut, sedih, lalai, kelinglungan, oleh karenanya memungkinkan dari seseorang suatu perkataan yang tidak memungkinkan, karena tidak keluar dari maksudnya dan kehendaknya. Maka jika semua itu terjadi pada seseorang maka harus diobati sesuai dengan penyakitnya.

\section{e. Pendidikan akhlak}

Pendidkikan akhlak memiliki makna yang strategis dalam pembangunan nasional, karena eksistensi suatu bangsa diukur dengan akhlak generasi mudanya, jika bangsa itu memiliki akhlak (karakter), maka bangsa itu akan tegak dan jaya, begitu juga sebaliknya. Olek karenanya tidak berlebihan nabi mengatakan "sesungguhnya aku di utus hanya untuk menyempurnakan akhlak" dan ketika siti 'aisyah di tanya bagaimana akhlak Rasulullah? Akhlak Rasul itu adalah al Quran. Artinya apapun yang Allah ajarkan kepadanya, maka Rasul segera merealisasikannya dalam perbuatan. Sehingga beliau diumpamakan seperti al Quran yang berjalan.

Pendidikan akhlak dimaksudkan membiasakan peserta didik terhadap akhlak mulia dan prilaku terpuji sehingga menjadi thabiat yang kukuh, dan sifat yang tetap yang ia berbahagia dengannya di dunia dan akhirat, dan terlepas dari akhlak yang jelek, karena anak itu tumbuh dengan apa yang dibiasakan oleh gurunya sejak kecil. $^{57}$

Akhlak yang baik terdiri dari lima pilar, sebagaimana Imam Ibnu Qoyyim mengungkapkan " sesungguhnya berdiri di atas lima pilar yaitu ilmu (karena dengannya diketahui akhlak yang tinggi dari yang rendah), dermawan, sabar (sabar dalam menjalaninya), perangi bagus (Allah telah di atas thabiat yang diikuti), dan islamnya benar. ${ }^{58}$

Kebanyakan orang melenceng akhlaknya disebabkan jeleknya pendidikan yang tumbuh padanya, ibnu Qoyyim mengatakan : "oleh kare itu kita banyak menemukan orang akhlaknya meenceng, hal itu dikarenakan dari sisi pendidikan yang tumbuh padanya"

\footnotetext{
${ }^{55}$ Hasan bin Ali Al Hijazi, Al Fikru At Tarbawi'inda Ibnil Qoyyim, 1988, Jeddah, Daar Al Hafidz, h.88

${ }^{56}$ Ibnu Qoyyim, Ighastatu al Lahfan min Musyayidi as Syaithon, hal. 28

${ }^{57}$ Ibnu Qayyim Al-Jauziyah, Tuhfatul Maudud Bi Akmamil Maulud: , h.240.

${ }^{58}$ Abu Daud, Tahdzib Sunan Abi Daud, 2001, Bairut, Daarul Ma'rifat. Hal. 7/162
} 
Pendidikan akhlak itu dengan menjaga anak agar tidak terjerembab dalam akhlak yang jelek, dan keji dari perkataan dan perbuatan, dan penjagaan ini menjadikan hati kosong dan menerima perkataan dn perbuatan yang baik.

Tujuan pendidikan akhlak menurut Imam Ibnu Qoyyim "merealisasikan ibadah kepada Allah yang dengannya manusia akan mendapatkan kebahagian, Allah yang telah menciptakannya dan menjadikannya kholifah di bumi tidak ada kebahagian baginya kecuali kecuali dihiasi dengan akhlak yang baik, adapun yang berakhlak jelak ia telah menyia-nyiakan kebahagiaan dunia dan akhirat"

Cara-cara pendidikan akhlak menurutnya adalah mengosongkan dan pengisian, mengikutsertakan peserta didik dalam mengerjakan kebaikan, pelatihan dan pembiasaan, menjauhi akhlak yang tercela, dan menjelaskan buah dari akhlak yang baik. Termasuk akhak yang baik diantaranya sabar, itsar, asysyukru dn lain sebagainya.

\section{f. Pendidikan karakter islami kemasyarakatan}

Masyarakat memiliki peranan penting dalam membentuk pribadi dari berbagai segi, baik pemikiran, sikap, prilaku dan perasaan. Maka seseorang yang berinteraksi dengan masyarakatnya dan terpengaruh dengan apa yang ada di dalamnya dari arahan-arahan, perangai, maka jadilah hal sebuah pondasi yang baik untuk sebuah bangunan. Kalau pendidikan masyarakat pada umumnya pendidikan islam seperti itu maka akan sampai pada tujuan pendidikan.

Pendidikan masyarakat yang ditunjukan Ibnu Qoyyim menciptakan ikatan kuat antar anggota masyarakat dari saling terikat da berpegangan yang dibangun di atas cinta kepada Allah sebagai realisasi dari pemahaman terhadap hadits Nabi saw yang berkata : tidak beriman seseorang diantaramu sehinggga mencintai saudranya seperti mencintai dirinya sendiri.HR Bukhori.

Imam Ibnu Qoyyim memerintahkan kita untuk menyambung di antara kita dan kaum kerabat dengan kebaikan, dan hubungan sesungguhnya dia memerintahkan untuk berbuat baik kepada kedua orang tua dan menyambung silaturrahmi dan itu suatu yang diperintahkan, dan dia memerintahkan untuk istriistri dengan menunaikan hak-hak mereka dan memperlakukan mereka dengan cara yang baik. Dan dia memmerintahkan kita menghubungi hamba sahaya untuk memberi makan, memberi pakaian dan tidak memebebani mereka di atas kemampuannya, dan memnghubungkan di antara kita dengan tetangga dekat dan jauh dengan menjaga haknya, dan memelihara dengan diri, harta, dan keluiarga seperti memelihara diri kira sendiri, keluarga dan harta kita. ${ }^{60}$

Pendidikan sosial masyarakat yang selamat menurut Ibnu Qoyyim adalah orang yang menjaga perasaan orang lain, maka seseorang dalam masyarakat Islami tidak boleh baginya menyakitkan saudara sekalipun hanya bau mulut yang tidak sedap. Beliau berkata : "sungguh Allah memerintahkan mukmunin di hari jum'at mandi dan memakai wewangian, supaya mereka berkumpul tidak menyakit satu dengan yang lainnya dengan bebauan yang mereka sentuh sebelum berkumpul, setelah itu berpisah kemudian dia melarang memakan bawang putih dan bawang merah memasuki mesjid supaya tidak menyakitkan kepada orang lain kbegitu juga kepada malaikat."

\footnotetext{
${ }^{59}$ Hasan bin Ali Al Hijazi, Al Fikru At Tarbawi'inda Ibnil Qoyyim, h 321

${ }^{60}$ Ibnu Qoyyi, Uddattishshobirin, Qairo, 2003, Daar Al Fajri, h. 21

${ }^{61}$ Ibid h 248
} 
Pendidikan kemasyarakatan yang konstruktif yang dikehendaki Imam Ibnu Qoyyim adalah : masyarakat yang menghasil individu-individu yang salaing mencintai satu sama liannya, dan mendo'akan satu dan yang lainnya sekalipun dari jauh, dengan hal ini malaikat mengamini atas do'a seorang laki-laki kepada sauadaranya.

Ibnu Qoyyim menyarankan kepada kedua orang tua untuk menjauhkan anakanaknya dari kemungkaran yang melingkupinya, dan kesesatan yang menyebar di dalamnya, karena anak bersih fitrahnya, jernih bathinnya, hatinya bagaikan lembaran putih yang bisa nebgukir padanya apapun yang menyentuhnya, beliau berkata : anak itu wajib dijauhkan jika sudah mengerti dari tempat-tempat main dan kebathilan, nyayian dan mendengarkan kekejian dan perkataan jelek. ${ }^{62}$

\section{g. Pendidikan karakter irodah (kehendak)}

Menurut bahasa irodah artinya kehendak atau keinginan. Sedangkan irodah menurut Ibnu Qoyyim adalan cita-cita yang membangkitkan seseorang untuk melakukan kerja, dan ia yang mewujudkan kepada manusia kebahagian dunia dan akhirat dan mencari keridhoan-Nya serta ilmu merupakan pintunya.

Ibnu Qoyyim sangat memperhatikan terhadap irodah yang meggerakkan terhadap cita-cita pelaku, kemudian beliau mengatakan ${ }^{63}$ : "Yang dimaksud Allah SWT memutuskan hikmah dan rahmat-Nya untuk mengeluarkan Adam dan keturunannya dari surga. Ia mengganti kepada mereka dengan apa yang lebih utama darinya yaitu apa yang diberikan kepada mereka berupa janji yang menjadikannya sebab menyampaikan mereka kepada-Nya. Barang siapa yang berpegang teguh kepada petunjuk-Nya dia akan sukses dan barangsiapa yang berpaling dia akan tersesat dan celaka. Janji yang mulia ini dan jalan yang lurus ini tidak akan sampai semuanya kecuali lewat pintu ilmu dan irodah, maka irodah itu pintu menyapaikan kepada-Nya dan ilmu adalah kunci pintu untuk membukanya.

Irodah itu salah satu karakter jiwa, Ibnu Qoyyim berpendapat bahwa jiwa itu mesti berkehendak, mungkin kehendak itu baik, mungkin juga buruk, selanjutnya beliau berkomentar : maka jiwa itu mesti berkeinginan melakukan, kalau tidak mendapat taufiq untuk melakukan amal sholeh, maka ia akan jauh dari kehendak yang buruk dan amal yang membahayakan.

Ibnu Qoyyim menyebutkan bahwa kesehatan irodah ada tanda-tandanya, tanda sehatnya irodah berkehendak untuk mendapatkan keridhoanny-Nya dan persiapan untuk menemui-Nya, dan kesedihannya atas waktu yang dilewati pada jalan yang diridhoi-Nya dan penyesalannya atas hilangnya waktu dekat dan senang dengan-Nya. Intisari semuanya hendaklah di waktu pagi dan sore tiadak baginya kebingunagan. ${ }^{64}$

Sesungguhnya irodah itu pekerjaan hati, dan irodah yang menyebabkan timbulnya harokah (kegiatan), dan pekerjaan pilihan, Ibnu Qoyyim memandang bahwa irodah ituciptaan Allah, Dialah yang menggerakan hati-hati dengan irodah dan anggota badan dengan berbagai amalan. Dan irodah sangat erat hubungannya mahabbah kepada Allah SWT.

\section{h. Pendidikan Badaniyah}

\footnotetext{
${ }^{62}$ Ibnu Qayyim Al-Jauziyah, Tuhfatul Maudud Bi Akmamil Maulud: , h.240

${ }^{63}$ Ibnu Qayyim Al-Jauziyah, Miftah Darus Sa'adah, h. 46

${ }^{64}$ Ibnu Qoyyim, Al Fawaaidz, tt, Qairo, Az Zahra, h 203
} 
Islam memberikan perhatian kepada badan, menjaga dan memberikan haknya secara seimbang, karena akan membantu kepada ta'at kepada Allah untuk melaksanakan kewajiban selaku mukmin hidup di dunia, Rasulullah bersabda : sesungguhnya jasadmu punya hak atasmu, matamu punya hak atasmu, maka berikanlah atas masing-masing haknya. Dan Rasul mengatakan " mukmin yang kuat lebih baik dan lebih dicintai oleh Allah daripada mukmin yang lemah. HR Ahmad.

Perhatian Ibnu Qoyyim terhadap badan datang dari dalam keyakinannya bahwa manusia itu kumpulan dari ruh, badan dan akal, dan sesungguhnya unsurunsur bekerja keras memikul beban yang tidak terpisahkan. Maka pendidikan yang benar memberikan bagi setiap unsur perhatiannya sesuai dengan yang dibutuhkan dari segi pendidikan dan arahan. Beliau mengingatkan bahwa badan butuh gizi baik dalam pola makan sebagaimana yang dicontohkan Rasululllah saw.

Badan itu terdiri dari tiga keadaan : sehat, sakit dan antara sehat dan sakit. Beliau mengatakan : "badan itu memiliki tiga keadaan alami kondisi sehat, keadaan luar dari kebiasaan dan keadaan pertengahan antara sehat dan sakit. ${ }^{65}$ Maka jika sakit dia menganjurkan berobat dan sehat dianjurkan menjaga, menjaga itu jauh lebih penting dari mengobati.

\section{i. Pendidikan sexual}

Termasuk hal yang perlu mendapatkan perhatian serius dari orang tua dan wali adalah pendidikan sexual, karena sudah difitrahkan pada manusia memiliki berbagai naluri diantaranya naluri sexual, baik laki-laki maupun perempuan, dan di zaman sekarang ini banyak terjadi kehancuran generasi muda yang ditimbulkan akibat penyimpangan dari fitrah asalnya dalam hal ini perzinahan, sodomi dan lesbian bahkan bestiality. Islam mengarah fitrah manusia supaya berjalan pada rel yang semestiya. Dan berdasar ini adanya pertikahan sebagai respon dari keinginan, dan syari'at mewadahi untuk menyalurkan naluri sexual sesuai dengan seharusnya,

Sesungguhnya dalam perbedaan sifat-sifat laki-laki dan perempuan ada tandatanda kebesaran Allah, dan Islam merupakan aturan-Nya yang diciptakan untuk memberi kemashlahatan bagi manusia dalam mengatur hubungannya dengan lawan jenis supaya mendapatkan kenikmatan,kebahagian, dan keselamatan didunia dan akhirat. Pertikahan dalam ajaran Islam diletakkan dengan tujuantujuan mulia, Ibnu Qoyyim mengingatkannya : "Jima itu diletakkan pada dasarnya untuk tiga hal tujuan pokok : salah satunya, menjaga keturunan, dan berkelanjutan jenis manusia, mengeluarkan cairan yang tertahan berbahaya keseluruh tubuh dan ketiga melampiaskan hajat dan mendapatkan kelejatan dan kenikmatankenikmatan. $^{66}$

Pola penerapan pendidikan karakter islami menurut Ibnu Qoyyim adalah pola penangan terpadu yang melibatkan semua elemen yang ada terkait dengan pembentukan karakter anak yaitu unsur lingkungan keluarga, lembaga pendidikan, dan pergaulan juga kebijakan pemerintah, pengosongan dan pengisian, mengaplikasikan kesembilan aspek pendidikan karakter, pelatihan dan pembiasaan, lari dari akhlak tercela, menjelaskan buah dari akhlak baik dan membimbing secara

\footnotetext{
65 Ibnu Qoyyim, Attibun Nabawi, Baerut, Daar Al Fikr, 1992, h 5

${ }^{66}$ Ibnu Qoyyim, Attibun Nabawi, h 194
} 
konsisten dan terus menerus sejak dini kebiasaan-kebiasaan baik sehingga membentuk karakter anak dengan tetap memberi kontrol dan pengawasan yang baik.pengawasan yang baik.

\section{DAFTAR PUSTAKA}

A. Susanto M.Pd., Pemikiran Pendidikan Islam, (Jakarta : Amzah, 2009)

Abdul majid, Dian andayani. Pedidikan karakter dalam perspektif Islam. (Bandung: Insan Cita Utama, 2010)

Abdullah Munir, Pendidikan Karakter Membangun Karakter Anak Sejak dari Rumah, (Yogyakarta : PT Bintang Pustaka Abadi, 2010.

Ahmad Tafsir, Ilmu Pendidikan dalam Perspektif Islam, (Bandung: PT Remaja Rosdakarya, 2005

Albertus, Doni Koesoema, Pendidikan Karakter Strategi Mendidik Anak di Zaman Global, (Jakarta: PT.Grasindo, 2010

Ali Abdul Halim Mahmud, Akhlak Mulia,Terj. Abdul Hayyi al-Kattienie dengan judul asli al-Tarbiyah al-Khuluqiyah, (Jakarta : Gema Insani Press, 2004

D. Marimba, Pengantar Filsafat Pendidikan Islam, (Bandung: Al-Ma'arif, 1989

Dharma Kesuma, Cepi Triatna, Johar Permana, Pendidikan Karakter Kajian Teori dan Praktik di Sekolah, (Bandung : Remaja Rosdakarya, 2011

Doni Koesoema A. Pendidikan Karakter: Strategi Mendidik Anak di Zaman Modern. (Jakarta: Grasindo, 2007

Erwin Yudi Prahara, Materi Pendidikan Agama Islam (Ponorogo: STAIN Po Press, 2009

Hasan bi Ali al Hijazi, Al Fikru At Tarbawi 'inda Ibnil Qoyyim, 1988, Daar al Hafidz

Hasan bin Ali Hasan Al-Hijazy, Manhaj Tarbiyah Ibnu Qayyim,Terjemahan Muzaidi Hasbullah, ( Jakarta : Al-Kautsar, 2001)

Heri Gunawan, Pendidikan Karakter Konsep dan Implementasi, (Bandung : Alfabeta, 2012

Ibnu Qayyim Al-Jauziyah, Ighasatul Lahfan min Mashidis Syaithan, Kairo : Daar Ibnul Jauzi, 1320 H,

Ibnu Qayyim Al-Jauziyah, Miftah Darus Sa'adah: Kunci Surga Mencari Kebahagiaan dengan Ilmu, terjemahan Abdul Matin dan Salim Rusydi Cahyono, Solo: Tiga Serangkai, 2009 h

Thomas Lickona, Educating For Character: How Our School Can Teach Respect and Responsibility, (New York:Bantam Books, 1992), h. 12-22. 
Ibnu Qayyim Al-Jauziyah, Tuhfatul Maudud Bi Akmamil Maulud, Bingkisan Kasih Untuk si Buah Hati, terjemahan Abu Umar Basyir al-Maedani, Solo: Pustaka Arafah, 2006

Ibnu Qayyim Al-Jauziyyah, Al-Jawab Al-Kafi: Mengetuk Pintu Ampunan Meraih Berjuta Anugerah, terjemahan Futuhal Arifin, ( Jakarta : Gema Madinah Makkah Pustaka, 2007),

Ibnu Qayyim Al-Jauziyyah, Kunci Surga: Mencari Kebahagiaan Dengan Ilmu, terjemahan Abdul Matin dan Salim Rusydi Cahyono, ( Solo : Tiga Serangkai, 2009),

Ibnu Qoyyim, Attibun Nabawi, Baerut, Daar Al Fikr, 1992

Ismail SM,,et al, Paradigma Pendidikan Islam, Semarang:Fakultas Tarbiyah IAIN Walisongo, 2001

Ki Hadjar Dewantara. Pendidikan. (Yogyakarta: Majelis Luhur Persatuan Taman Siswa

M. Furqon Hidayatulloh, Pendidikan Karakter Membangun Peradaban Bangsa, (Surakarta : Yuma Pressindo, 2010

M. Mahbubi, Pendidikan Karakter Implementasi Aswaja sebagai Nilai Pendidikan Karakter, (Yogyakarta : Pustaka Ilmu, 2012

Marfu', Perbedaan pendidikan karakter dengan pendidikan akhlak, pendidikan moral, dan pendidikan nilai, http:// risetpendidikangmarfu'.com, Diakses pada tanggal 20 Mei 2014.

Marzuki, Pendidikan Al-Qur'an dan Dasar-dasar Pendidikan Karakter dalam Islam, Makalah, (Jogjakarta, tt

Masnur Muslich, Pendidikan Karakter Menjawab Tantangan Krisis Multidimensional, (Jakarta : Bumi Aksara, 2011

Moleong, Lexy J. Metode penelitian kwalitatif. Bandung. 1989. Remaja Karya.

Ni'matulloh.et. all, Pendidikan Karakter Dalam Persfektif Pendidikan Islam, (http://nimatlloh. blogspot.com, diakses pada tanggal 20 Mei 2014)

Rukyah Toha al Jabir, Tajkiyatu an Nafsi, Qaira Mesir, Daar at Taqwa, $1428 \mathrm{H}$

Sudirman N, Ilmu Pendidikan, (Bandung: Remaja Rosdakarya, 1987),

Suparlan Suhartono, Wawasan Pendidikan, Sebuah Pengantar Pendidikan, (Yogyakarta : Ar-Ruzz Media, 2008 